"Przegląd Prawa Konstytucyjnego" - Nr 1 (17)/2014 ------

\title{
Recenzja
}

\section{Jarosław Szymanek, Ustrój konstytucyjny Kazachstanu, Wydawnictwo Elipsa, Warszawa 2013, ss. 232}

Kiedy Autor przesłał mi tę książkę, od razu zorientowałem się, że to opracowanie jest pierwszą w naszej literaturze próbą całościowego ujęcia wspólczesnego, konstytucyjnego ustroju Republiki Kazachstanu i w tym znaczeniu ma ono charakter pionierski. Chociażby już tylko z tego tytułu zasługuje ono na recenzyjne odnotowanie jego publikacji.

Dla Autora ważnym punktem odniesienia, a zarazem merytorycznym i ukierunkowującym wsparciem była praca autorstwa T. Bodio i T. Mołdawy pt. Konstytucje państw Azji Centralnej. Tradycje i współczesność, wydana w Warszawie w 2007 r., oraz zamieszczone w tej pracy tłumaczenie Konstytucji Republiki Kazachstanu autorstwa P. Załęskiego. W tym kontekście praca o konstytucyjnym ustroju Kazachstanu przedstawia się jako naturalna kontynuacja politologicznych badań nad polityczno-ustrojową transformacją państw poradzieckiej Azji Centralnej, od dłuższego czasu prowadzonych w Instytucie Nauk Politycznych Uniwersytetu Warszawskiego. Naturalnym jest, że intensyfikujące się przemiany polityczne z czasem nabierają wymiaru normatywno-ustrojowego i zasadniczo w tym obszarze sytuuje się przedmiot pracy.

Rzecz obejmuje czternaście rozdziałów spiętych klamrą wstępu i zakończenia. Rozdział pierwszy, stanowiący zarys historii kazachskiego konstytucjonalizmu, ma charakter wprowadzający. W moim przekonaniu prezentacja, chociażby syntetyczna, kazachskiej i kazachstańskiej myśli ustrojowej jest uzasadniona i konieczna. Otóż Kazachowie, podobnie jak pokrewni im Tatarzy, postrzegają siebie jako spadkobierców państwa Czyngis-chana i Złotej Ordy oraz ich kulturalnego dorobku. I nie jest to tylko slogan stwo- 
rzony na użytek politycznych elit, ale współcześnie mocno ugruntowane społeczne przekonanie tych społeczeństw, o czym może świadczyć ich stanowcza i krytyczna reakcja wobec niedawno stworzonego przez kinematografię rosyjską obrazu zatytułowanego Złota Orda. W rozdziale pierwszym pracy wspomina się między innymi takie pomniki tamtejszego prawa ustrojowego, jak „kodeks” pt. Prawdziwe postanowienia Quazim-chana z pierwszej połowy XVII w. czy „kodeks” pt. Żeti Żargy z okresu istnienia chanatu Tauke na przełomie XVIII i XIX w. Były to ujednolicone spisy praw zwyczajowych. Dodajmy, że pionierem badań nad zwyczajowym prawem Kazachów był Polak - jeden z najwybitniejszych zesłańców, Seweryn Gross ${ }^{1}$ autor fundamentalnej pracy pt. Materiały do studiów nad kirgiskim prawem zwyczajowym².

Kolejność dalszych rozdziałów w znacznym stopniu koresponduje z systematyką obowiązującej Konstytucji Republiki Kazachstanu z 1995 r. I tak, kolejne rozdziały pracy traktują o: konstytucyjnych podstawach ustroju państwa, konstytucyjnych prawach i wolnościach jednostki, prawie wyborczym i systemie partyjnym, systemie organów państwowych, prezydencie Republiki Kazachstanu, parlamencie z jego izbami: Mażilisem - izbą pierwszą i Senatem - izbą drugą, następnie o rządzie, systemie rządów, ustawodawstwie, Radzie Konstytucyjnej, sądach i wymiarze sprawiedliwości, władzy lokalnej oraz - co wyraźnie wykracza poza systematykę konstytucji - o stanach nadzwyczajnych.

Kazachstański konstytucjonalizm jest konstytucjonalizmem relatywnie młodym i, co z tym związane, poszukującym optymalnych dla siebie wzorców i kierunków rozwoju. Praktycznie jedynymi rodzimymi wzorcami ustrojowymi dla odrodzonego Kazachstanu były wzorce radzieckie i przedradzieckie, w tym żuzowo-trybalne. Jako tym wartościowsze należy postrzegać deklaracje i próby nawiązywania przez współczesny Kazachstan do europejskich tradycji i rozwiązań ustrojowych. Kazachstański konstytucjonalizm znajduje się w fazie zmian i rozwoju. Z tym większym zainteresowaniem wypada zatem monitorować proces kształtowania się systemu rządów, który w założeniu zmierza ku kanonom demokracji. Praca J. Szymanka jest

1 Patrz: A. Milewska-Młynik, Seweryn Gross wśród badaczy kazachskiego prawa zwyczajowego, Warszawa 2012.

2 S. Gross, Matieriały dlia izuczienija juridiczieskich obyczajew Kirgizow, 1888. 
wartościową próbą uchwycenia momentu, w jakim znajduje się transformujący się system ustrojowy Republiki Kazachstanu.

Wiodącą i charakterystyczną cechą współczesnego, konstytucyjnego ustroju Republiki Kazachstanu jest dominująca pozycja ustrojowa jej prezydenta. Jego ustrojowe kompetencje są tak szerokie, pozycja polityczna tak mocna, a autorytet tak znaczący, że wymyka się on zachodnim wzorcom prezydenckiego systemu rządów, a tym bardziej kanonom parlamentarnego systemu rządów. Intensywna, praktyczna wykładnia konstytucyjnej zasady prezydenckiej formy rządów w połączeniu z konstytucyjną zasadą jednolitości władzy państwowej skutkuje lokowaniem prezydenta RK poza albo ponad zasadą trójpodziału władzy, co Autor zauważa i podkreśla. Prezydent Republiki jest między innymi najwyższą odwoławczą instancją od rozstrzygnięć władzy wykonawczej, pomimo tego, że formalnie nie stanowi elementu tej władzy. Dodajmy, że dominująca pozycja prezydenta jest zjawiskiem typowym dla wszystkich państw poradzieckiej Azji Centralnej.

Współczesny Kazachstan formułuje swoje dalekosiężne cele ustrojowe jako ustanowienie demokracji i rządów prawa, i wartości te znajdują w Kazachstanie swój konstytucyjny wyraz. Jednocześnie wartościami, które mają tam duże społeczne znaczenie, także w opinii urzędującego prezydenta, są stabilność, efektywność, pewność i przewidywalność, co nie zawsze harmonijnie współgra z praktykowaniem demokracji, której nie da się z dnia na dzień przeszczepić na nie do końca przygotowany do tego grunt. Stąd - jak zauważa Autor - prezydent RK traktuje demokrację jako cel ambitnego, dalekosiężnego projektu, który powinien być osiągany stopniowo, ewolucyjnie, w miarę kształtowania się poszczególnych instytucji demokratycznych, takich jak: prawo, instytucje polityczne, kultura prawna itd. Stąd w opinii prezydenta nie jest możliwe automatyczne, natychmiastowe, całkowite, pełne i konsekwentne przeszczepienie europejskich standardów na kazachstański grunt. Obiektywnie nie jest zadaniem łatwym przeprowadzić państwo i społeczeństwo $\mathrm{z}$ formacji totalitarnej do formacji demokratycznego państwa prawnego w pełnym tego pojęcia znaczeniu. Jednym z celów nakreślonych przez prezydenta i rząd Republiki jest dążenie do budowy społeczeństwa obywatelskiego. Wymaga to między innymi stworzenia w Kazachstanie od podstaw samorządu terytorialnego, z którym to wyzwaniem przychodzi się obecnie mierzyć tamtejszym władzom i społeczeństwu. 
Jedną z interesujących kazachstańskich instytucji konstytucyjnych jest Rada Konstytucyjna - odpowiednik sądu konstytucyjnego, wzorowany na analogicznych, technicznych rozwiązaniach francuskich. Ustanowienie organu badającego konstytucyjność prawa zawsze jest postrzegane jako krok ku budowie państwa prawnego. Ale i wobec rady konstytucyjnej prezydent ma znaczące kompetencje, pozwalające mu sprawować nad nią - jak podnosi J. Szymanek - rodzaj kurateli.

Obok komentarza do poszczególnych, normatywnie wyrażonych instytucji i procedur ustrojowych praca uwzględnia także prezentacje czynników o charakterze materialnym, to jest czynników społeczno-ekonomicznych, które stanowią przecież składową konstytucji rzeczywistej. Przykładowo można wskazać na interesujące informacje i uwagi dotyczące trybalizmu oraz żuzów, to jest klanowo-terytorialnych struktur, spetryfikowanych w społecznej świadomości Kazachów do tego stopnia, że w latach 90. minionego wieku rozważano ich konstytucjonalizację. Według ówczesnej koncepcji miały one stanowić podmioty składowe federacji. Kazachski trybalizm jako swoista mutacja prawa zwyczajowego stanowi pewne uzupełnienie litery kazachstańskiej konstytucji.

Recenzowana pozycja, poza tym, że poszerza naszą wiedzę o ustroju Kazachstanu, dostarcza ważnego materiału dla komparatystycznych badań ustrojowych w dwóch kontekstach. Po pierwsze, materiał ten jest pomocny w ocenie intensywności wpływu europejskich rozwiązań ustrojowych na konstytucyjny ustrój Kazachstanu. Po drugie, materiał ten może być wykorzystany do porównań kazachstańskich instytucji ustrojowych z analogicznymi instytucjami pozostałych państw regionu poradzieckiej Azji Centralnej, czyli: Kirgistanu, Tadżykistanu, Turkmenistanu i Uzbekistanu. Można domniemywać, że w następnej kolejności Autor zaangażuje się w badania nad ustrojami konstytucyjnymi tych właśnie państw. Praca ta z pewnością poszerza naszą ustrojową optykę wciąż relatywnie słabo poznanego przez nas Kazachstanu i dostarcza impulsu dla rozwijania i podejmowania dalszych badań nad instytucjami ewoluującego, konstytucyjnego ustroju tego państwa.

Andrzej Bisztyga Górnośląska Wyższa Szkoła Handlowa im. Wojciecha Korfantego w Katowicach 